\title{
Taxonomic significance of epidermal and venation characters in the genus Diospyros L. (Ebenaceae) in Nigeria
}

\section{Opeyemi Philips Akinsulire*, Olaniran Temitope Oladipo, Olawale Abdullahi Abdulraheem, Akinwumi Johnson Akinloye and Herbert Chukwuma Illoh}

Department of Botany. Obafemi Awolowo University. Ile-Ife. Nigeria. *Email: opeyemiakinsulire@gmail.com.

\begin{abstract}
This study investigated the foliar anatomy and venation patterns of thirteen species of the genus Diospyros in Nigeria with a view to identifying characters of great taxonomic value in the genus. Plant collections were made from different locations in Southwest Nigeria and the site of collection georeferenced with a GPS device. Samples were identified at the Herbarium of Botany Department, Obafemi Awolowo University (IFE). Voucher Specimens were deposited in the herbarium and voucher number assigned to each of the species. The samples were subjected to foliar epidermal and venation examinations. Qualitative data were recorded as the quantitative data were subjected to statistical analysis and the characters vary significantly $(P=0.05)$. Epidermal and venation characters which separate the taxa include stomata type, size and index, shape and size of epidermal cell, trichome type, presence/ absence of crystal/druses, as well as venation. Paxillate venation in D. suaveolens is diagnostic for the species. The presence of parenchymatous sheath over the veins and veinlets in $D$. tricolor is a spot character. The study reveals that leaf epidermal and venation characters are important in delimitation of species in the genus Diospyros.
\end{abstract}

Keywords: Classificatory; Diagnostic; Paxillate; Reticulate; Spot character.
Received

May 29, 2018

Accepted

August 21, 2018

Released

August 31, 2018

Full Text Article

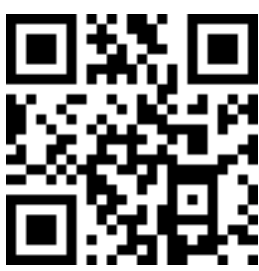

ORCID

(C) 0000-0001-8063-4908 Opeyemi Philips Akinsulire

D 0000-0003-2957-2961

Olaniran Temitope

Oladipo

ㄴ) 0000-0002-8618-7974

Olawale Abdullahi

Abdulraheem

(C) 0000-0003-4256-862X

Akinwumi Johnson

Akinloye

(C) 0000-0003-1994-4012

Herbert Chukwuma

Illoh 


\section{Introduction}

The genus Diospyros belongs to the family Ebenaceae (Ebony family). Ebenaceae is pantropical in distribution with about 500 species (Wallnofer, 2001). They are mainly represented by trees and shrubs with most species evergreen, but some are deciduous (Halle et al., 1978). In the family, leaves are simple, usually alternate, rarely opposite to sub opposite or in pseudowhorls of three, spirally or distichously arranged, petiolate or rarely sub sessile, induplicate or involutes in bud; stipules absent; lamina of leaves is coriaceous in many species, less frequently chartaceous, pinnately veined; leaf margins usually entire, very seldom finely crenulate, usually with strongly revolute margins at base, at least when dry; leaf apices spinose in some species.

The Ebenaceous inflorescence is conventionally referred to as a cyme $(\mathrm{Ng}$, 1991). Solitary flowers are always terminal on the peduncle. Usually, male flowers of a given species by far outnumber the females. The actinomorphic flowers range from trimerous, pentamerous to octamerous. The number of floral parts is known to vary within species and cannot, therefore, be used effectively for their distinctions, as has been done in the past (Wallnofer, 2001). The fruit is 1-16 seeded multiloculate, usually indehiscent berries which is subtended by a persistent 3-8-lobed calyx. White (1983) posited that fruits of some African species of Diospyros sect. Royena become dry, and occasionally tardily dehiscent. In no species of Ebenaceae, however, is the fruit completely and spontaneously dehiscent. Seeds are often dispersed by various fruit-eating animals, such as civet cats, monkeys (Tutin et al., 1996). Ebenaceae are the source of several economically important products, the most valuable being their fruits and timber (ebony) and the genus Diospyros is best known for producing dense black wood (ebony) and tasty fruit (e.g. persimmons and zapotes) (Casper, 2013).

Most of the revisions of the genus Diospyros have been based on field observation and macromorphological characters (Wickremasinghe and Herat, 2006). In view of the complex taxonomic status in the genus, this study therefore set out to describe the leaf epidermal morphology and venation pattern of thirteen species of the genus Diospyros with a view to providing useful additional information for the delimitation and subsequent identification of members of the genus, thereby enhancing the taxonomic revision of the genus. The representative species of the genus include D. undabunda, D. mespiliformis,

D. iturensis, D. canaliculata,

D. precatorium, D. physocalycina,

D. crassiflora, D. tricolor, D. suaveolens,

D. dendo, D. conocarpa, D. nigerica and D. barteri.

\section{Materials and methods}

\section{Study area and target species}

The present study was carried out in south-western Nigeria between Longitude $2^{\circ} 31^{\prime}$ and $6^{\circ} 00^{\prime} \mathrm{E}$ and latitude $6^{\circ} 21^{\prime}$ and $8^{\circ} 37^{\prime} \mathrm{N}$ (Agboola, 1979). The climate of South-Western Nigeria is majorly tropical, characterised by wet and dry seasons with temperature ranging between $21^{\circ} \mathrm{C}$ and $34^{\circ} \mathrm{C}$ and annual rainfall of about $150 \mathrm{~mm}$ to $3,000 \mathrm{~mm}$ (Faleyimu et al., 2013). Collection of plants was made from different locations in Southwest Nigeria and the site of collection was georeferenced with a GPS device (Table 1, Figure 1). Thirteen species were considered in this study, five accessions were considered for each species and ten matured leaves examined from different parts of the plants for each of the accessions.

\section{Epidermal study}

Sizeable portions from the leaves of the species studied were taken from 
standard median portion of the leaf while the scrape method of Metcalfe (1968) was used to obtain the epidermis. After scraping, the scraped portion was carefully cut and the peels were stained in Safranin 0, rinsed in three to four changes of water and then mounted in $25 \%$ glycerol on a clean glass slide for light microscopy.

\section{Venation pattern}

Sizeable portions of the matured leaf of each of the species were obtained from the standard median portion of the leaf. The materials were decolorized by boiling in $90 \%$ ethanol at $20{ }^{\circ} \mathrm{C}$ for about 10-15 min (to remove chlorophyll), then washed in 3-4 changes of water to remove all traces of alcohol. The portions were then transferred to $5 \%$ Sodium Hydroxide and boiled for $30 \mathrm{~min}$ for further decolourization. The materials were later washed thoroughly to remove alkaline solution. The partially cleared leaves were further cleared in 5\% domestic bleach (sodium hypochlorite) for 20-30 min under sunlight The portions were again washed in 3-4 changes of water, stained in Safranin 0 and counter stained in Alcian Blue (to enhance contrast), rinsed with water (to remove excess stain) before being mounted in $25 \%$ glycerol on a clean slide for examination under light microscope.

\section{Data analysis}

Data generated from the documentation were subjected to Analysis of Variance and Multivariate Statistical Analysis. Photomicrographs of all epidermal and venation features were made with the aid of Accu-scope 33001 LED Trinocular Microscope with 3.2 MP CMOS Digital Camera. All quantitative parameters were taken with the aid of ocular micrometer and final figures derived with ocular constant.

Table 1. Collection Site, Geographical Coordinates and Voucher Number of Diospyros species Studied.

\begin{tabular}{|c|c|c|c|}
\hline Species & Collection site & $\begin{array}{l}\text { Geographical } \\
\text { Coordinates }\end{array}$ & $\begin{array}{l}\text { Voucher } \\
\text { Number }\end{array}$ \\
\hline D. barteri & $\begin{array}{l}\text { Buffer Forest SNRI, Omo Forest } \\
\text { Reserve, Omo, Ogun State. }\end{array}$ & $\begin{array}{l}+6^{\circ} 58^{\prime} 44.23^{\prime} \mathrm{N} \\
+4^{\circ} 22^{\prime} 4.23^{\prime} \mathrm{E}\end{array}$ & IFE 17385 \\
\hline D. canaliculata & $\begin{array}{l}\text { Osokun Road, Omo Forest } \\
\text { Reserve, Omo, Ogun State }\end{array}$ & $\begin{array}{l}+6^{\circ} 51^{\prime} 49.14^{\prime} \mathrm{N} \\
+4^{\circ} 23^{\prime} 42.83^{\prime} \mathrm{E}\end{array}$ & IFE 17387 \\
\hline D. conocarpa & $\begin{array}{l}\text { Buffer Forest SNRI, Omo Forest } \\
\text { Reserve, Omo, Ogun State. }\end{array}$ & $\begin{array}{l}+6^{\circ} 58^{\prime} 44.23^{\prime} \mathrm{N} \\
+4^{\circ} 22^{\prime} 4.23^{\prime} \mathrm{E}\end{array}$ & IFE 17389 \\
\hline D. crassiflora & $\begin{array}{l}\text { Along the way to Etemi, Omo } \\
\text { Forest Reserve, Omo, Ogun State. }\end{array}$ & $\begin{array}{l}+6^{\circ} 58^{\prime} 19.53^{\prime} \mathrm{N} \\
+4^{\circ} 22^{\prime} 21.27^{\prime} \mathrm{E}\end{array}$ & IFE 17391 \\
\hline D. dendo & $\begin{array}{l}\text { Buffer Forest SNRI, Omo Forest } \\
\text { Reserve, Omo, Ogun State. }\end{array}$ & $\begin{array}{l}+6^{\circ} 58^{\prime} 44.23^{\prime} \mathrm{N} \\
+4^{\circ} 22^{\prime} 4.23^{\prime} \mathrm{E}\end{array}$ & IFE 17386 \\
\hline D. iturensis & $\begin{array}{l}\text { Along the way to Etemi, Omo } \\
\text { Forest Reserve, Omo, Ogun State. }\end{array}$ & $\begin{array}{l}+6^{\circ} 58^{\prime} 19.53^{\prime} \mathrm{N} \\
+4^{\circ} 22^{\prime} 21.27^{\prime} \mathrm{E}\end{array}$ & IFE 17315 \\
\hline D. mespiliformis & $\begin{array}{l}\text { Botany Department, University of } \\
\text { Ibadan, Oyo State }\end{array}$ & $\begin{array}{l}+7^{\circ} 23^{\prime} 28.19^{\prime} \mathrm{N} \\
+3^{\circ} 54^{\prime} 59.99^{\prime} \mathrm{E}\end{array}$ & IFE 17308 \\
\hline
\end{tabular}


Table 1. Continued.

\begin{tabular}{|c|c|c|c|}
\hline Species & Collection site & $\begin{array}{l}\text { Geographical } \\
\text { Coordinates }\end{array}$ & $\begin{array}{l}\text { Voucher } \\
\text { Number }\end{array}$ \\
\hline D. nigerica & $\begin{array}{l}\text { Buffer Forest SNRI, Omo Forest } \\
\text { Reserve, Omo, Ogun State. }\end{array}$ & $\begin{array}{l}+6^{\circ} 58^{\prime} 44.23^{\prime} \mathrm{N} \\
+4^{\circ} 22^{\prime} 4.23^{\prime} \mathrm{E}\end{array}$ & IFE 17392 \\
\hline D. physocalycina & $\begin{array}{l}\text { Along the way to Etemi, Omo } \\
\text { Forest Reserve, Omo, Ogun } \\
\text { State. }\end{array}$ & $\begin{array}{l}+6^{\circ} 58^{\prime} 19.53^{\prime} \mathrm{N} \\
+4^{\circ} 22^{\prime} 21.27^{\prime} \mathrm{E}\end{array}$ & IFE 17388 \\
\hline D. precatorium & $\begin{array}{l}\text { Osokun Road, Omo Forest } \\
\text { Reserve, Omo, Ogun State }\end{array}$ & $\begin{array}{l}+6^{\circ} 51^{\prime} 49.14^{\prime} \mathrm{N} \\
+4^{\circ} 23^{\prime} 42.83^{\prime} \mathrm{E}\end{array}$ & IFE 17616 \\
\hline D. suaveolens & $\begin{array}{l}\text { Osokun Road, Omo Forest } \\
\text { Reserve, Omo, Ogun State }\end{array}$ & $\begin{array}{l}+6^{\circ} 51^{\prime} 49.14^{\prime} \mathrm{N} \\
+4^{\circ} 23^{\prime} 42.83^{\prime} \mathrm{E}\end{array}$ & IFE 17595 \\
\hline D. tricolor & $\begin{array}{l}\text { Botanical Garden, University of } \\
\text { Lagos, Akoka, Lagos State }\end{array}$ & $\begin{array}{l}+6^{\circ} 30^{\prime} 59.99^{\prime} \mathrm{N} \\
+3^{\circ} 23^{\prime} 5.99^{\prime} \mathrm{E}\end{array}$ & IFE 17595 \\
\hline D. undabunda & $\begin{array}{l}\text { Osokun Road, Omo Forest } \\
\text { Reserve, Omo, Ogun State }\end{array}$ & $\begin{array}{l}+6^{\circ} 51^{\prime} 49.14^{\prime} \mathrm{N} \\
+4^{\circ} 23^{\prime} 42.83^{\prime} \mathrm{E}\end{array}$ & IFE 17384 \\
\hline
\end{tabular}

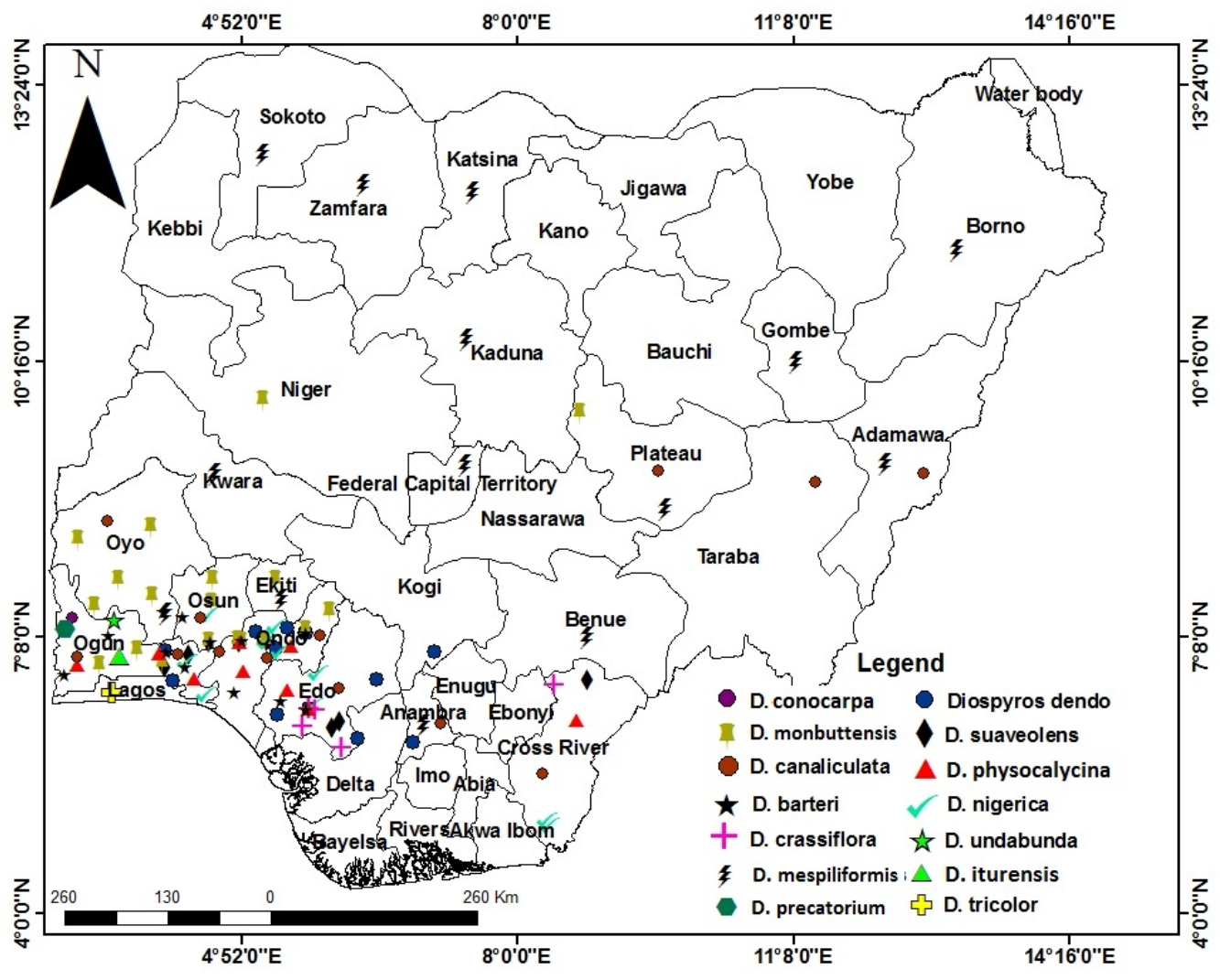

Figure 1. Map of Nigeria showing Diospyros species distribution. 


\section{Results}

\section{Diospyros undabunda Leaf epidermis and venation pattern}

On the adaxial surface, epidermal cells are generally polygonal, ranging from triangular to pentagonal, anticlincal walls straight to undulating, size varies between 11.00-15.40 $\mu \mathrm{m}$ long and 4.40$11.00 \mu \mathrm{m}$ wide. Epidermal cell ranges between 208 and $242 \mathrm{~mm}^{-}$, stomata are absent (Figure 2A). On the abaxial surface, epidermal cells ranges from triangular to pentagonal with wavy anticlinal walls, anticlinal walls sometimes straight, epidermal cell size ranges between $11.00-24.60 \mu \mathrm{m}$ long and 6.60-19.80 $\mu \mathrm{m}$ wide, epidermal cell ranges between 112 to $130 \mathrm{~mm}^{-2}$, stomata type is cyclocytic, guard cell mostly circular occasionally elliptic, mean stomata size $67.0 \pm 2.8 \mu \mathrm{m}$ long and $47.0 \pm 2.0 \mu \mathrm{m}$ wide, stomata frequency $10-15 \mathrm{~mm}^{-2}$, mean stomata index is $10.45 \%$ (Figure $3 \mathrm{~A}$ ). On the veins, venation is regular polygonal reticulate, areoles are well developed, shape ranges from triangular to pentagonal, size about 200.20-582.40 $\mu \mathrm{m}$ long and 127.40-382.20 $\mu \mathrm{m}$ wide. Veins are simple, curved or branched, occasionally forked, vein density 0-4 per areole (Figure 4A)

\section{Diospyros mespiliformis Leaf epidermis and venation pattern}

Epidermal cells are largely irregular on the adaxial surface, anticlinal walls sinuous, cells about twice longer than wide, size ranges between 13.20-22.00 $\mu \mathrm{m}$ long and 6.60-13.20 $\mu \mathrm{m}$ wide, epidermal cell number ranges between 186 to $212 \mathrm{~mm}^{-2}$; stomata are absent (Figure 2B). On the abaxial surface, epidermal cells are irregular, anticlinal wall is sinuous, cells about twice longer than wide, cell size ranges from $13.20-24.20 \mu \mathrm{m}$ long and 6.60$13.20 \mu \mathrm{m}$ wide, epidermal cell number ranges between 152 to $176 \mathrm{~mm}^{-2}$, stomata type is paracytic, guard cell mostly circular and occasionally elliptic, stomata frequency around $11-18 \mathrm{~mm}^{2}$, mean stomata size about $77.0 \pm 2.1 \mu \mathrm{m}$ long to $54.0 \pm 1.5 \mu \mathrm{m}$ wide, mean stomata index is $9.04 \%$ (Figure 3B). On the veins, venation is regular polygonal reticulate, areoles are well developed, shape largely polygonal, sometimes irregular, size ranges from 245.70$764.40 \mu \mathrm{m}$ long and 145.60-527.80 $\mu \mathrm{m}$ wide; veins simple; branched and occasionally forked; vein density 0-3 per areole (Figure 4B).

\section{Diospyros canaliculata Leaf epidermis and venation pattern}

Epidermal cells are irregular, anticlinal walls are wavy with variable sizes, ranging from $8.80-15.40 \mu \mathrm{m}$ long to 6.60-11.00 $\mu \mathrm{m}$ wide, epidermal cell number also varies between 211-229 cells $\mathrm{mm}^{-2}$, stomata absent (Figure 2C). On the abaxial surface, epidermal cells are predominantly irregular with wavy anticlinal walls, cells variable in size, ranging from $11.00-17.60 \mu \mathrm{m}$ long to 6.60-11.00 $\mu \mathrm{m}$ wide, epidermal cell number ranges between $160-187 \mathrm{~mm}^{2}$; stomata staurocytic, stomata frequency about 28-38 per $\mathrm{mm}^{2}$; mean stomata size is $66.0 \pm 2.1 \mu \mathrm{m}$ long and $46.0 \pm 1.9 \mu \mathrm{m}$ wide, mean stomata index up to $13.73 \%$, guard cell are mostly circular (Figure 3C). On the veins, venation is regular polygonal reticulate, areoles well developed, shape ranges from triangular to pentagonal, size ranges from 282.10$773.50 \mu \mathrm{m}$ long to $182.00-491.40 \mu \mathrm{m}$ wide; veins simple and branched; occasionally forked; 0-2 per areole (Figure 4C). 

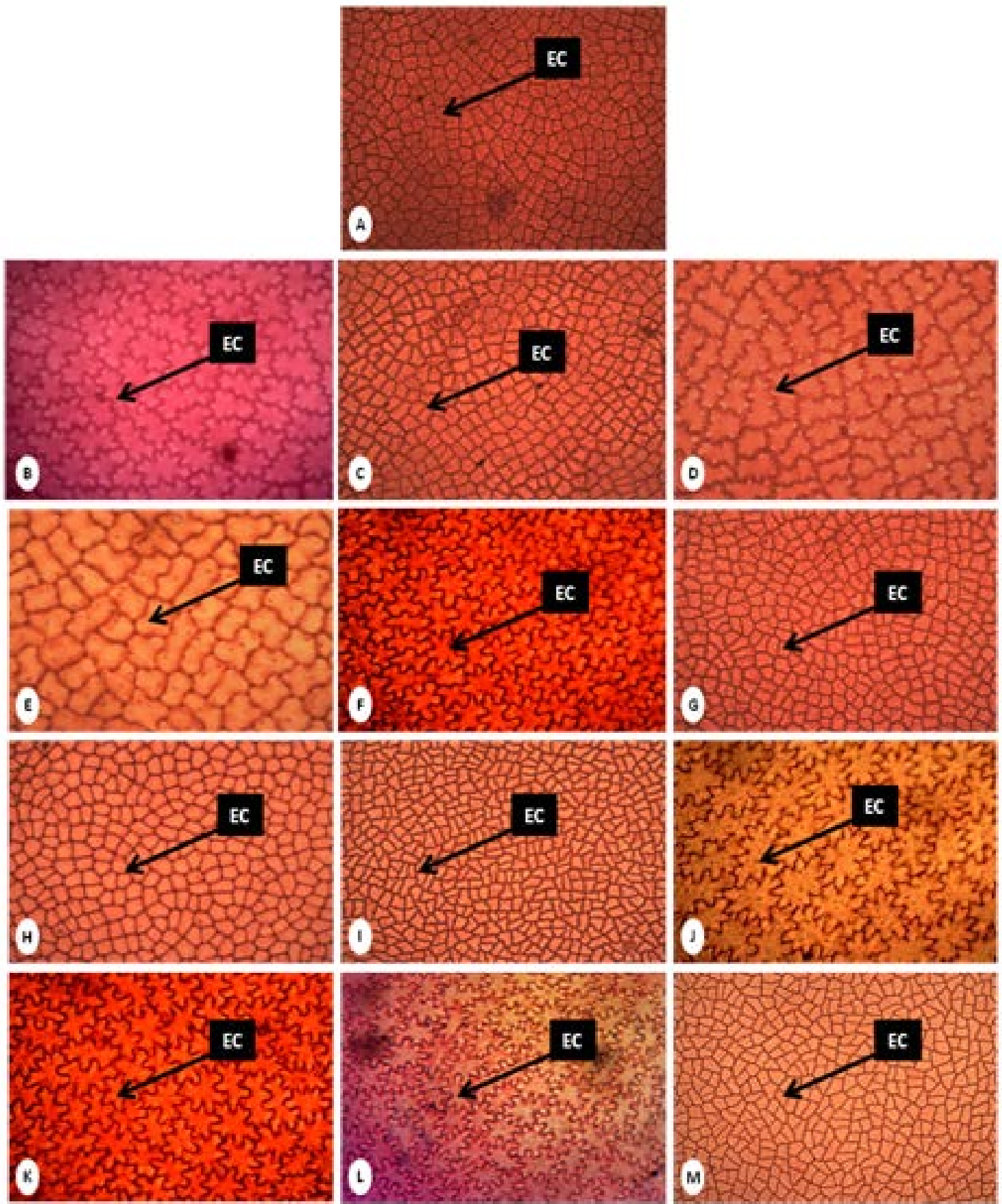

426 man

Figura 2. Photomicrograph of Adaxial Surfaces of Thirteen species of Diospyros. EC=Epidermal Cell, $\mathbf{A}=D$. undabunda, $\mathbf{B}=D$. mespiliformis, $\mathbf{C}=D$. iturensis, $\mathbf{D}=D$. canaliculata, $\mathbf{E}=D$. precatorium, $\mathbf{F}=$ D. physocalycina, $\mathbf{G}=D$. crassiflora, $\mathbf{H}=D$. tricolor, $\mathbf{I}=D$. suaveolens, $\mathbf{J}=D$. dendo, $\mathbf{K}=D$. conocarpa, $\mathbf{L}=$ D. nigerica, $\mathbf{M}=D$. barteri. 


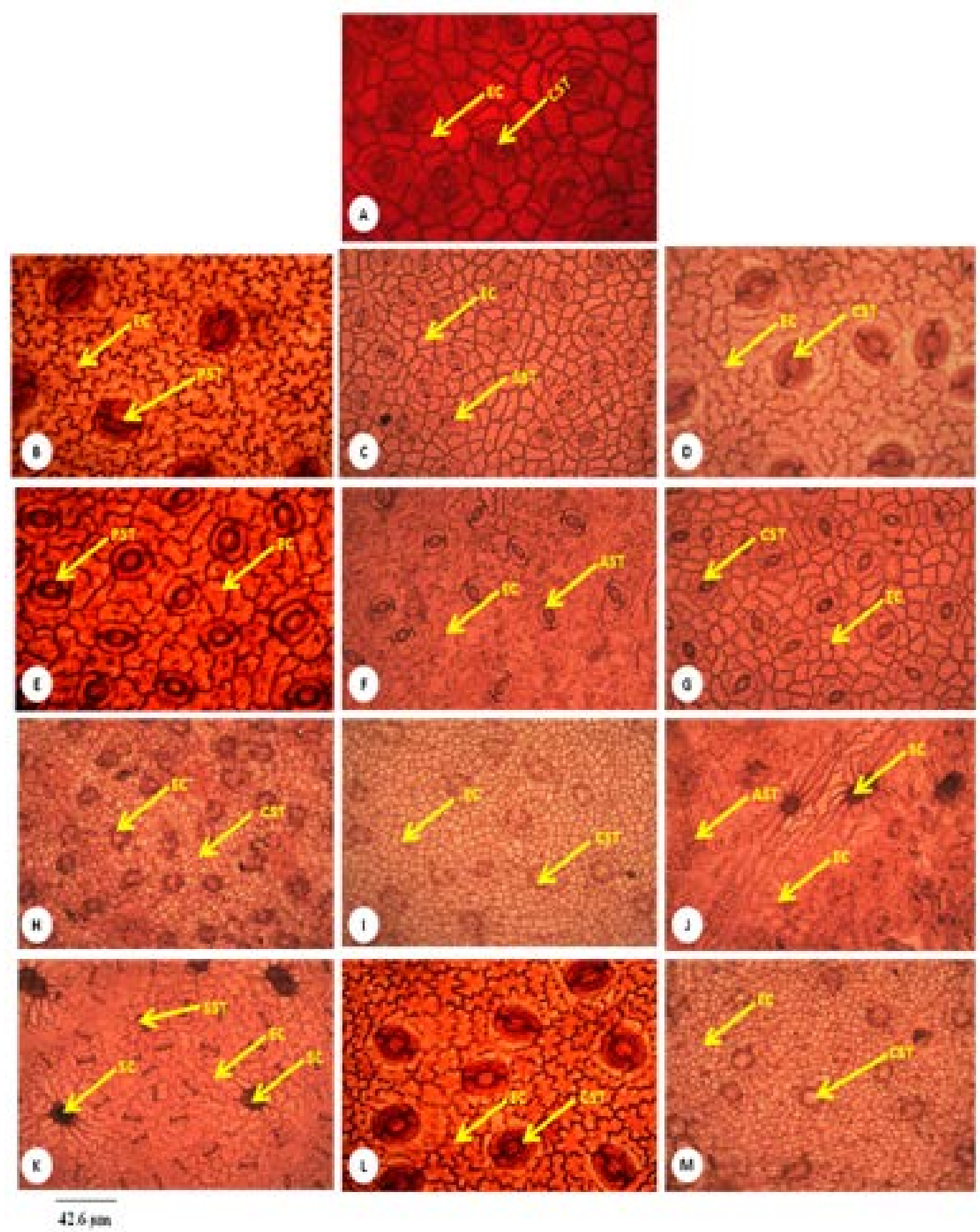

Figure 3. Photomicrograph of Abaxial Surfaces of Thirteen species of Diospyros. EC = Epidermal Cell, CST = Cyclocytic Stomata, PST = Paracytic Stomata, SST = Staurocytic Stomatata, AST = Anomocytic Stomata, $\mathbf{S C}=$ Scale. $\mathbf{A}=$ D. undabunda, $\mathbf{B}=$ D. mespiliformis, $\mathbf{C}=D$. iturensis, $\mathbf{D}=D$. canaliculata, $\mathbf{E}=$ D. precatorium, $\mathbf{F}=$ D. physocalycina, $\mathbf{G}=$ D. crassiflora, $\mathbf{H}=$ D. tricolor, $\mathbf{I}=D$. suaveolens, $\mathbf{J}=$ D. dendo, $\mathbf{K}=$ D. conocarpa, $\mathbf{L}=$ D. nigerica, $\mathbf{M}=$ D. barteri. 

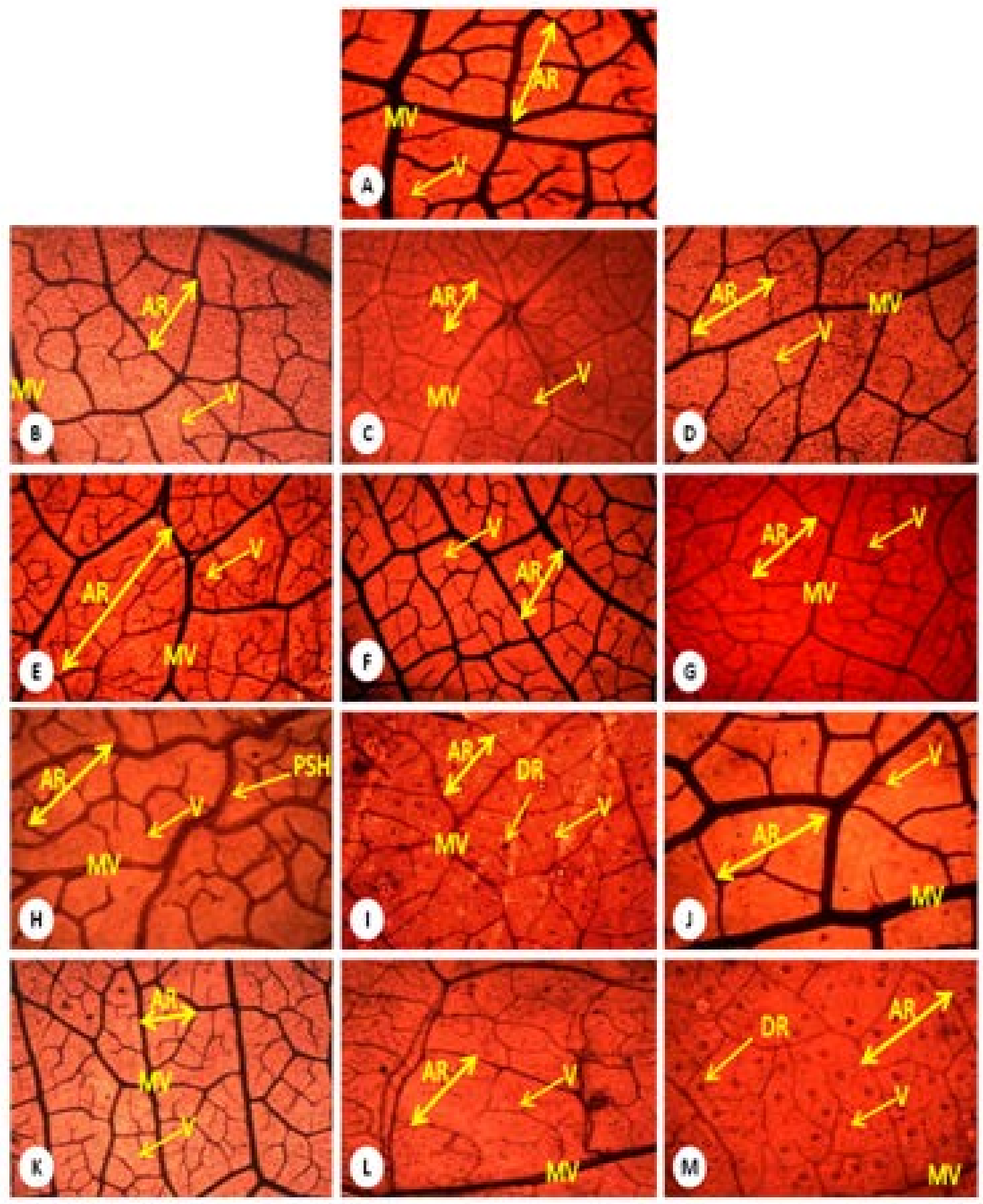

\section{$426 \mathrm{ma}$}

Figure 4. Photomicrograph of Venation Pattern of Thirteen species of Diospyros. AR $=$ Areole, $\mathbf{V}=$ Vein, $\mathbf{M V}=$ Main Vein, $\mathbf{P S H}=$ Parenchymatous Sheath, $\mathbf{D R}=$ Druses, $\mathbf{A}=$ D. undabunda, $\mathbf{B}=D$. mespiliformis, $\mathbf{C}=$ D. iturensis, $\mathbf{D}=$ D. canaliculata, $\mathbf{E}=$ D. precatorium, $\mathbf{F}=$ D. physocalycina, $\mathbf{G}=D$. crassiflora, $\mathbf{H}=$ D. tricolor, $\mathbf{I}=$ D. suaveolens, $\mathbf{J}=$ D. dendo, $\mathbf{K}=$ D. conocarpa, $\mathbf{L}=$ D. nigerica, $\mathbf{M}=D$. barteri. 

pattern

\section{Diospyros iturensis}

Leaf epidermis and venation

Epidermal cells mostly rectangular, anticlinal walls straight to undulating, epidermal cell number ranges between $188-208 \mathrm{~mm}^{2}$, size ranges between 13.20-22.00 $\mu \mathrm{m}$ long and 6.60-13.20 $\mu \mathrm{m}$ wide; stomata absent (Figure 2D). On the abaxial surface, epidermal cells generally polygonal, anticlinal walls wavy to undulating, size ranges between $13.20-26.40 \mu \mathrm{m}$ long and 8.80-15.40 $\mu \mathrm{m}$ wide; epidermal cell number ranges between 128 and 168 $\mathrm{mm}^{2}$; stomata type largely cyclocytic; guard cell is mostly elliptic, mean stomata size $67.0 \pm 1.9 \mu \mathrm{m}$ long and $49.0 \pm 2.0 \mu \mathrm{m}$ wide, stomata frequency $11-15 \mathrm{~mm}^{2}$; mean stomata index is $7.28 \%$ (Figure 3D). On the veins, venation is regular polygonal reticulate, areoles well developed, sometimes irregular, size ranges from 291.20$709.80 \mu \mathrm{m}$ long and 136.50-382.20 $\mu \mathrm{m}$ wide; veins simple; branched and forked; vein density 0-4 per areole (Figure 4D).

\section{Diospyros precatorium Leaf epidermis and venation pattern}

Epidermal cells generally polygonal on the adaxial surface, anticlinal wall straight to slightly wavy, cell varies in size ranging between11.00$13.25 \mu \mathrm{m}$ long and 17.60-18.09 $\mu \mathrm{m}$ wide; epidermal cell number ranges between 210 to $232 \mathrm{~mm}^{2}$, stomata absent (Figure 2E). On the abaxial, epidermal cells generally polygonal, anticlinal walls wavy to sinuous, size ranging between 13.20-26.40 $\mu \mathrm{m}$ long and 8.80-11.00 $\mu \mathrm{m}$ wide; epidermal cell number varies from 161-188 per $\mathrm{mm}^{2}$, stomata type is paracytic, mean stomata size is $63.0 \pm 1.8$ $\mu \mathrm{m}$ long and $44.0 \pm 1.9 \mu \mathrm{m}$ wide, stomata frequency $32-43 \mathrm{~mm}^{2}$, mean stomata index 17.21\%, guard cell elliptic (Figure $3 \mathrm{E})$. On the veins, venation is regular polygonal reticulate, Areoles well developed; shape generally polygonal, size ranges from 354.90-755.30 $\mu \mathrm{m}$ long to $172.90-482.30 \mu \mathrm{m}$ wide; veins simple, branched and occasionally forked; vein density 0-6 per areole (Figure 4E).

\section{Diospyros physocalycina Leaf Epidermis and Venation Study}

On the adaxial surface, epidermal cell are largely irregular, anticlinal wall is sinuous, cell size ranges between 11.00$15.40 \mu \mathrm{m}$ long and 6.60-11.00 $\mu \mathrm{m}$ wide, epidermal cell number ranges between 184 and 208 cells $\mathrm{mm}^{2}$, stomata are absent on the adaxial surface (Figure 2F). On the abaxial surface, epidermal cells are largely irregular, anticlinal walls sinuous, size ranges between 15.40$26.40 \mu \mathrm{m}$ long and 11.00-19.80 $\mu \mathrm{m}$ wide, Epidermal cell number ranges between $110-132 \mathrm{~mm}^{2}$, stomata type is anomocytic, stomata frequency 10-17 $\mathrm{mm}^{2}$, mean stomata size is $61.0 \pm 1.70$ $\mu \mathrm{m}$ long and $36.0 \pm 1.70 \mu \mathrm{m}$ wide, mean stomata index is $11.76 \%$, guard cell elliptic (Figure 3F). On the veins, venation is regular polygonal reticulate, areoles perfectly formed, shape mostly polygonal, size ranges between 245.70$728.00 \mu \mathrm{m}$ long and 109.20-309.40 $\mu \mathrm{m}$ wide; veins mostly forked, occasionally simple linear, vein density is $0-3$ per areole (Figure 4F).

\section{Diospyros crassiflora Leaf epidermis and venation study}

On the adaxial surface, epidermal cells are rectangular to pentagonal with straight to undulating anticlinal walls, size ranges between 11.00-17.60 $\mu \mathrm{m}$ long and 6.60-11.00 $\mu \mathrm{m}$ wide, epidermal cell number varies between 204-232 cells $\mathrm{mm}^{2}$, stomata absent (Figure 2G). On the abaxial, epidermal cell are largely polygonal, anticlinal wall straight slightly wavy, size 11.00-19.80 $\mu \mathrm{m}$ long and 6.60$13.20 \mu \mathrm{m}$ wide, epidermal cell number 75-92 $\mathrm{mm}^{2}$, stomata cyclocytic, guard cell elliptic, mean stomata size is $65.0 \pm 1.8 \mu \mathrm{m}$ long and $46.0 \pm 1.3 \mu \mathrm{m}$ wide, stomata frequency $7-12 \mathrm{~mm}^{2}$, mean stomata index is $9.80 \%$ (Figure 
3G). On the veins, venation is regular polygonal reticulate, areoles well developed, largely polygonal, size ranges from 218.40-691.60 $\mu \mathrm{m}$ long and 109.20$391.30 \mu \mathrm{m}$ wide, veins is simple, branched and occasionally forked, vein density is $0-3$ per areole (Figure 4G).

\section{Diospyros tricolor \\ Leaf epidermis and venation pattern}

On the adaxial surface, epidermal cells are polygonal, mostly pentagonal, anticlinal wall straight to undulating, size ranges between 8.80-17.60 $\mu \mathrm{m}$ long and 6.60-11.00 $\mu \mathrm{m}$ wide; epidermal cell number ranges between $200-224 \mathrm{~mm}^{2}$, stomata absent (Figure 2H). On the abaxial surface, epidermal cells are polygonal, mostly pentagonal, anticlinal walls straight to undulating, cells variable in size, ranging from 11.00$17.60 \mu \mathrm{m}$ long and 6.60-11.00 $\mu \mathrm{m}$ wide, epidermal cell number about 120-136 $\mathrm{mm}^{2}$, stomata cyclocytic, guard cells elliptic, mean stomata size is $57.0 \pm 1.5$ $\mu \mathrm{m}$ long and $40.0 \pm 1.2 \mu \mathrm{m}$ wide, stomata frequency $10-14 \mathrm{~mm}^{2}$, mean stomata index is $9.03 \%$ (Figure $3 \mathrm{H}$ ). On the veins, venation is regular polygonal reticulate, areoles well develop, size ranges from 182.00-464.10 $\mu \mathrm{m}$ long and 100.1$263.90 \mu \mathrm{m}$ wide, veins mostly simple, occasionally forked or linear, vein density 0-2 per areole. Parenchymatous sheath surround veins and veinlets (Figure 4H).

\section{Diospyros suaveolens Leaf epidermis and venation study}

Epidermal cell largely rectangular to hexagonal, anticlinal walls straight to undulating, size variable, ranging from 8.80-13.20 $\mu \mathrm{m}$ long and 6.60-8.80 $\mu \mathrm{m}$ wide, epidermal cell ranges between $274-304 \mathrm{~mm}^{2}$, stomata absent (Figure 2I). On the abaxial, epidermal cells are largely rectangular, occasionally irregular, anticlinal walls straight to undulating, size ranges from 13.20-26.40 $\mu \mathrm{m}$ long and 8.80-15.40 $\mu \mathrm{m}$ wide, epidermal cell varies from 161-184 per $\mathrm{mm}^{2}$, stomata type is cyclocytic with elliptic guard cell, stomata frequency about $10-13$ per $\mathrm{mm}^{2}$, mean stomata size is $67.0 \pm 2.0 \mu \mathrm{m}$ long and $50.0 \pm 1.9 \mu \mathrm{m}$ wide, mean stomata index is $6.45 \%$ (Figure 3I). On the veins, venation is paxillate, Areoles is imperfect, occurring in oriented fields, shape ranges from triangular to pentagonal, size ranges from 191.10-518.70 $\mu \mathrm{m}$ long and 100.10$245.70 \mu \mathrm{m}$ wide, veins mostly linear, vein density 0-2 per areoles; druses present in the areoles (Figure 4I).

\section{study}

Diospyros dendo

Leaf epidermis and venation

On the adaxial surface, epidermal cells are largely irregular with deeply sinuous anticlinal walls, size ranges between 15.40-19.80 $\mu \mathrm{m}$ long and 8.80$15.40 \mu \mathrm{m}$ wide, epidermal cell number ranges between 161-189 per $\mathrm{mm}^{2}$, stomata absent (Figure 2J). On the abaxial surface, epidermal cells are irregular with wavy anticlinal walls, size ranges between 13.20-22.00 $\mu \mathrm{m}$ long and 6.60-13.20 $\mu \mathrm{m}$ wide, epidermal cell number about $117-134 \mathrm{~mm}^{2}$, stomata anomocytic, mean stomata size is $56.0 \pm 1.5 \mu \mathrm{m}$ long and $37.0 \pm 1.5 \mu \mathrm{m}$ wide, mean stomata index $7.81 \%$, stomata frequency $9-13 \mathrm{~mm}^{2}$, scales present, trichome frequency $0-5 \mathrm{~mm}^{2}$ (Figure 3J). On the veins, venation is regular polygonal reticulate, areoles moderately developed, shape ranges from triangular to pentagonal, size ranges from 309.40-873.60 $\mu \mathrm{m}$ long and 191.10-482.30 $\mu \mathrm{m}$ wide, veinlet ending simple, branched and occasionally forked, vein density is $0-2$ per areole (Figure 4J).

\section{Diospyros conocarpa Leaf epidermis and venation pattern}

On the adaxial surface, epidermal cells are largely irregular with deeply sinuous anticlinal walls, size ranging between 17.60-24.20 $\mu \mathrm{m}$ long and 6.60- 
$13.20 \mu \mathrm{m}$ wide, epidermal cell number ranges between $231-249 \mathrm{~mm}^{2}$, stomata are absent (Figure 2K). On the abaxial, epidermal cells are irregular, anticlinal walls are wavy or slightly sinuous, size ranges between 11.00-26.40 $\mu \mathrm{m}$ long and 6.60-19.80 $\mu \mathrm{m}$ wide, epidermal cell number $120-138 \mathrm{~mm}^{2}$, stomata is staurocytic, guard cells are elliptic, mean stomata size about $69.0 \pm 1.4 \mu \mathrm{m}$ long and $44.0 \pm 1.7 \mu \mathrm{m}$ wide, mean stomata index $10.49 \%$, stomata frequency $12-18$ $\mathrm{mm}^{2}$, scales present, trichomes frequency 0-6 per field (Figure 3K). On the veins, venation is regular polygonal reticulate, areoles are well developed, shape ranges from triangular to pentagonal, 318.5-819.00 $\mu \mathrm{m}$ long and 154.70-382.20 $\mu \mathrm{m}$ wide, veins are simple, occasionally forked, vein density 0-3 per areole (Figure $4 \mathrm{~K}$ )

\section{Diospyros nigerica Leaf epidermis and venation pattern}

On the adaxial surface, epidermal cells are irregular, with deeply sinuous anticlinal walls, size ranging between 17.60-22.00 $\mu \mathrm{m}$ long and 8.80-13.20 $\mu \mathrm{m}$ wide, epidermal cell number ranges between 140-159 $\mathrm{mm}^{2}$, stomata absent (Figure 2L). On the abaxial surface, epidermal cells are irregular, anticlinal walls sinuous, sometimes wavy, size ranges between $13.20-19.80 \mu \mathrm{m}$ long and 8.80-13.20 $\mu \mathrm{m}$ wide, epidermal cell number $122-133 \mathrm{~mm}^{2}$; stomata largely cyclocytic, guard cell is elliptic, mean stomata size is $64.0 \pm 1.9 \mu \mathrm{m}$ long and $40.0 \pm 2.5 \mu \mathrm{m}$ wide, stomata frequency $12-16 \mathrm{~mm}^{2}$, mean stomata index is $9.52 \%$ (Figure 3L). On the veins, venation is dichotomizing, areoles well developed, shape largely rectangular to hexagonal, size ranges between 291.20$718.90 \mu \mathrm{m}$ long and 136.80-427.70 $\mu \mathrm{m}$ wide, veins are simple branched and occasionally forked, vein density 0-2 per areole (Figure 4L).

\section{Diospyros barteri pattern Leaf epidermis and venation}

On the adaxial surface, epidermal cells are polygonal, anticlinal walls straight to undulating, epidermal cell number ranges between 221-240 per $\mathrm{mm}^{2}$; size ranges between 19.80-24.20 $\mu \mathrm{m}$ long and 8.80-11.00 $\mu \mathrm{m}$ wide, stomata absent (Figure 2M). On the abaxial surface, epidermal cells are polygonal with straight to undulating anticlinal walls, size ranges between 11.00-26.40 $\mu \mathrm{m}$ long and 8.00-15.40 $\mu \mathrm{m}$ wide, epidermal cell number 162-186 $\mathrm{mm}^{2}$; stomata largely cyclocytic, guard cells are mostly elliptic, mean stomata size is $56.0 \pm 1.7 \mu \mathrm{m}$ long and $41.0 \pm 1.7$ $\mu \mathrm{m}$ wide, stomata frequency $10-13 \mathrm{~mm}^{2}$, mean stomata index is $5.88 \%$ (Figure $3 \mathrm{M})$. On the veins, venation is regular polygonal reticulate, areoles well developed, shape ranges from triangular to pentagonal, size ranges from 227.50$673.40 \mu \mathrm{m}$ long and 145.60-500.50 $\mu \mathrm{m}$ wide, veins mostly linear, vein density 0 2 per areole, druses are present and numerous (Figure 4M).

\section{Discussion}

\section{Foliar Epidermal Morphology and Venation Pattern}

Leaves in the taxa studied are generally hypostomatic and it is considered a character of unification in the genus, hence their generic classification. However, while this finding contradicts the work of $\mathrm{Ng}$ (1971), who reported that stomata can be found on both surface of the leaf in $D$. mespiliformis, it corroborates Schadel \& Dickson (1979) who pointed out that stomata are usually anomocytic and occur only on abaxial leaf surfaces in genus Diospyros. On the adaxial surfaces of all the taxa, sinuous anticlinal walls can be used in grouping D. mespiliformis, 
D. physocalicina, $D$. dendo, $D$. conocrpa and D. nigerica (Figure 2B, F, J, K and L) while the anticlinal walls of all other species ranges from straight to wavy (Figure 2A, C, D, E, G, H, I and M). However, on the abaxial surfaces, D. mespiliformis, D. precatorium, D. physocalicina, D. conocarpa and D. nigerica can be classified on the account of slightly sinuous to sinuous anticlinal walls (Figure 3B, E, F, K and L). Significant variations exist on both the type of stomata and distribution in the genus studied. The species can be grouped into four on the account of the type of stomata present. D. physocalycina and $D$. dendo are classified by anomocytic stomata on the abaxial surface (Figure $3 \mathrm{~F}$ and I). This observation is also in line with Schadel and Dickson (1979). D. canaliculata and D. conocarpa are grouped by staurocytic stomata (Figure 3C and $\mathrm{K}$ ), while D. mespiliformis and D. precatorium are characterized by paracytic stomata (Figure $3 \mathrm{~B}$ and $\mathrm{E}$ ), hence classificatory for the species. Other species as $D$. undabunda, D. iturensis, $D$. crassiflora, $D$. tricolor, $D$. suaveolens, $D$. nigerica and $D$. barteri are classified by cyclocytic stomata (Figure 3A, D, G, H, J, L and $\mathrm{M})$. However, the presence of cyclocytic stomata in some species of Diospyros has previously been reported by Stace (1965) and Wallnofer (2001) who both posited that some species in the genus Diospyros possess cyclocytic stomata and that their subsidiary cells differ somewhat in shape, size and orientation, and in having straight anticlinal walls. The quantitative foliar epidermal character of $D$. mespliformis shows a significant longer and wider stomata length and width as $D$. dendo possesses the least, $D$. precatorium also has the highest stomata density with $D$. crassiflora having the least hence separating the species (Table 2). The influence of trichome morphology and distribution in the taxonomy of different groups of plants has been well documented by Adedeji et al. (2007) in the delimitation of genera and species within the family Solanaceae. Rammaya and Rao (1976) and Rao and Rammaya (1977) have also emphasized the taxonomic importance of trichomes in the family Malvaceae. In this study, the presence of scales on the abaxial surfaces of $D$. dendo and D. conocarpa is classificatory for the two species (Figure $3 \mathrm{~J}$ and $\mathrm{K}$ ). This reflects their level of closeness and monophyletic origin. The presence of scales in the two species aligns with the report of Wallnofer (2001) who reported that scale hairs are present on some African species of Ebenaceae.

Foliar venation has proven to be useful in delimitation of species (Levin 1986a). Leaf venation among many other characters of leaf is considerably different in each species, though constant among members of the same species (Provance and Sanders, 2006). In this study, irregular as well as welldeveloped triangular to polygonal areolation pattern which are peculiar and prominent in all the species studied suggests a generic character. The presence of 0 - 6 vein density per areole in $D$. precatorium is a spot character for the species (Figure 4E). The imperfect areole in D. suaveolens (Figure 4I) is diagnostic for the species as all others possess perfect areoles. The species can be grouped into two on the basis of their nature of veins and veinlets: Simple or unbranched veinlets found in $D$. suaveolens and D. barteri is classificatory (Figure 4I and $\mathrm{M}$ ) while branched veinlets found in the rest of the taxa can be used in grouping them. D. dendo is distinctly separated from the rest of the species by the possession of significantly longer and wider areole (Table 3). On the contrary $D$. suaveolens is uniquely delineated from other species by the possession of significantly smaller areole size (Table 3). The occurrence of numerous druses in the areoles of $D$. suaveolens and D. barteri classifies the taxa and indicates a level of taxonomic relationship between the two species (Figure 4I and M). Meanwhile, the 
importance of crystals in taxonomy has been highlighted by many scientists including Amos (1951) as well as Illoh and Inyang (1998). Ter Welle (1976) also emphasized that the mode of distribution of crystals is also an important taxonomic tool. The presence of parenchymatous sheath only in $D$. tricolor (Figure $4 \mathrm{H}$ ), as well as paxillate venation in D. suaveolens (Figure 4I) (as other species are grouped by their regular polygonal reticulate venation) are diagnostic for the species and are of great taxonomic value. The dendogram of the species (Figure 5) revealed that $D$. mespiliformis and D. canaliculata as well as D. physocalicina and D. conocarpa are classified to the highest level of similarity as every other members of the genus (except D. undabunda) shared some generic relationship with them indicating they are recently evolved. However, $D$. undabunda is very distant to every other taxa hence its primitiveness. The similarity observed in $D$. mespiliformis and D. canaliculata as well as D. physocalicina and D. conocarpa is evident in their quantitative epidermal and venation characters and common ancestry. The PCA scattered diagram (Figure 6) revealed the similarities in the genus. It clustered the species into two groups on the basis of their similarity and differences. The closeness observed between $D$. iturensis, $D$. nigerica, $D$. conocarpa, D. crassiflora and D. bateri and D. canaliculata as well as $D$. precatorium, $D$. canaliculata and $D$. mespiliformis is a function of the similarities in their leaf and venation taxonomic characters. This study therefore reveals that foliar epidermal and venation characters are important in delimitation of species in the genus Diospyros and should be used as basis for taxonomy.

Table 2. Foliar epidermal characters (abaxial and adaxial surfaces) of thirteen species of Diospyros with Duncan Multiple Range Test.

\begin{tabular}{|c|c|c|c|c|c|c|c|c|c|}
\hline & \multicolumn{3}{|c|}{ Adaxial } & \multicolumn{6}{|c|}{ Abaxial } \\
\hline & NEC & $\begin{array}{c}\text { ECL } \\
(\mu \mathrm{m})\end{array}$ & $\begin{array}{l}\text { ECW } \\
(\mu \mathrm{m})\end{array}$ & SD & $\begin{array}{c}\text { SL } \\
(\mu \mathrm{m})\end{array}$ & $\begin{array}{c}\text { SW } \\
(\mu \mathrm{m})\end{array}$ & NEC & $\begin{array}{c}\text { ECL } \\
(\mu \mathrm{m})\end{array}$ & $\begin{array}{l}\text { ECW } \\
(\mu \mathrm{m})\end{array}$ \\
\hline D. undabunda & $222.5^{\mathrm{d}}$ & $129.9^{\mathrm{fg}}$ & $7.8^{\mathrm{e}}$ & $13.8^{\text {ed }}$ & $67.3^{b}$ & $47.3^{\mathrm{bc}}$ & $121.7 \mathrm{e}$ & $18.6^{\mathrm{b}}$ & $13.9^{a}$ \\
\hline D. mespiliformis & $199.2^{\mathrm{g}}$ & $18.6^{\mathrm{bc}}$ & $9.0^{\mathrm{cd}}$ & $15.1^{\mathrm{c}}$ & $76.9^{a}$ & $54.1^{\mathrm{a}}$ & $163.9^{\mathrm{b}}$ & $18.0^{\mathrm{bc}}$ & $9.6^{\text {cde }}$ \\
\hline D. iturensis & $196.7 \mathrm{~g}$ & $16.7^{d}$ & $10.7^{a b}$ & $12.7 \mathrm{ef}$ & $66.8^{\mathrm{bc}}$ & $49.4^{\mathrm{ab}}$ & $128.1^{d}$ & $18.4^{b}$ & $10.7 \mathrm{bcd}$ \\
\hline D. canaliculata & $219.4 \mathrm{e}$ & $12.0 \mathrm{~g}$ & 7.9de & $30.5^{b}$ & $64.8 \mathrm{bc}$ & $46.3 \mathrm{bc}$ & $174.5^{\mathrm{a}}$ & $13.3^{f}$ & $8.9 \mathrm{e}$ \\
\hline D. precatorium & $222.5^{\mathrm{de}}$ & $15.0 \mathrm{e}$ & $8.3^{\mathrm{de}}$ & $40.6^{a}$ & $63.7 \mathrm{bc}$ & $43.6^{\text {cde }}$ & $175.1^{\mathrm{a}}$ & $14.5^{\text {ef }}$ & $9.6^{\text {cde }}$ \\
\hline D. physocalycina & $197.2 \mathrm{~g}$ & $12.6^{\mathrm{g}}$ & $8.8^{\mathrm{de}}$ & $14.2^{\mathrm{cd}}$ & $61.4^{\mathrm{cd}}$ & $37.1^{\mathrm{f}}$ & $121.9^{\mathrm{e}}$ & $20.9^{a}$ & $14.2^{\mathrm{a}}$ \\
\hline D. crassiflora & $219.4 \mathrm{e}$ & $14.5^{\mathrm{e}}$ & $8.4 \mathrm{de}$ & $9.4 \mathrm{~h}$ & $65.1^{b c}$ & $45.5 \mathrm{bcd}$ & $83.7 \mathrm{f}$ & 15.3def & 9.9cde \\
\hline D. tricolor & $211.3^{\mathrm{f}}$ & $13.9 \mathrm{ef}$ & $9.0^{\mathrm{cd}}$ & $11.8^{\mathrm{fg}}$ & $57.3^{\mathrm{de}}$ & $40.0^{\mathrm{ef}}$ & $125.5^{\mathrm{d}}$ & $14.6^{\mathrm{ef}}$ & $9.0^{\mathrm{de}}$ \\
\hline D. suaveolens & $292.1^{a}$ & $11.9 \mathrm{~g}$ & 7.9de & $11.2^{\mathrm{g}}$ & $67.3^{\mathrm{b}}$ & $49.6^{\mathrm{ab}}$ & $172.6^{\mathrm{a}}$ & $18.4^{\mathrm{b}}$ & $10.9 \mathrm{bc}$ \\
\hline D. dendo & $179.1^{\mathrm{h}}$ & $17.6^{\mathrm{cd}}$ & $11.3^{\mathrm{a}}$ & $11.1 \mathrm{~g}$ & $55.5^{\mathrm{e}}$ & $37.3^{\mathrm{f}}$ & $125.5^{\mathrm{de}}$ & $17.2^{\mathrm{bcd}}$ & $10.3^{\text {bcde }}$ \\
\hline D. conocarpa & $239.1^{\mathrm{b}}$ & $19.6^{\mathrm{b}}$ & $10.3^{\mathrm{ab}}$ & $15.3^{\mathrm{c}}$ & $64.2^{\mathrm{bc}}$ & $39.6^{\mathrm{ef}}$ & $125.7 \mathrm{de}$ & $17.2^{\mathrm{bcd}}$ & $11.8^{\mathrm{b}}$ \\
\hline D. nigerica & $151.6^{\mathrm{i}}$ & $19.6^{\mathrm{b}}$ & $11.4^{\mathrm{a}}$ & $13.7^{\mathrm{de}}$ & $69.2^{b}$ & 43.7 cde & $128.1^{\mathrm{d}}$ & 15.9cde & $10.0^{\text {cde }}$ \\
\hline D. barteri & $231.9^{c}$ & $21.7^{a}$ & $10.0^{\mathrm{bc}}$ & $11.5 \mathrm{~g}$ & $56.4 \mathrm{de}$ & 40.9 def & $176.3^{\mathrm{a}}$ & $166.3^{\text {bcde }}$ & $10.5^{\mathrm{bcde}}$ \\
\hline
\end{tabular}

*means with the same alphabet along the same column are not significantly different. SDStomata Density, SL- Stomata Length, SW- Stomata Width, NEC - Number of Epidermal Cells, ECL Epidermal Cells Length, ECW - Epidermal cell Width. 
Table 3. Quantitative parameters of venation pattern in thirteen species of Diospyros with Duncan Multiple Range Test.

\begin{tabular}{|c|c|c|c|}
\hline & Areole length $(\mu \mathrm{m})$ & Areole width $(\mu \mathrm{m})$ & Vein density \\
\hline D. undabunda & $289.8^{e}$ & $190.2^{e f}$ & $0-4$ \\
\hline D. mespiliformis & $549.2^{b c}$ & $278.5^{a b c}$ & $0-3$ \\
\hline D. iturensis & $546.8^{b c}$ & $226.2^{\text {cde }}$ & $0-4$ \\
\hline D. canaliculata & $583.9^{a b}$ & $295.6^{a b}$ & $0-2$ \\
\hline D. precatorium & $488.2^{b c}$ & $256.1^{b c d}$ & $0-6$ \\
\hline D. physocalycina & $458.9^{c d}$ & $218.7 d e$ & $0-3$ \\
\hline D. crassiflora & $511.4^{b c}$ & $244.8^{\text {bcd }}$ & $0-3$ \\
\hline D. tricolor & $289.8^{e}$ & $151.1 f g$ & $0-2$ \\
\hline D. suaveolens & $287.1^{e}$ & $129.7 \mathrm{~g}$ & $0-2$ \\
\hline D. dendo & $640.6^{a}$ & $314.9^{a}$ & $0-2$ \\
\hline D. conocarpa & $579.2^{a b}$ & $256.6^{b c d}$ & $0-3$ \\
\hline D. nigerica & $495.9^{b c}$ & $251.6^{b c d}$ & $0-2$ \\
\hline D. barteri & $482.8^{c}$ & $249.8^{\text {bcd }}$ & $0-2$ \\
\hline
\end{tabular}

*Means with the same alphabet along the same column are not significantly different.

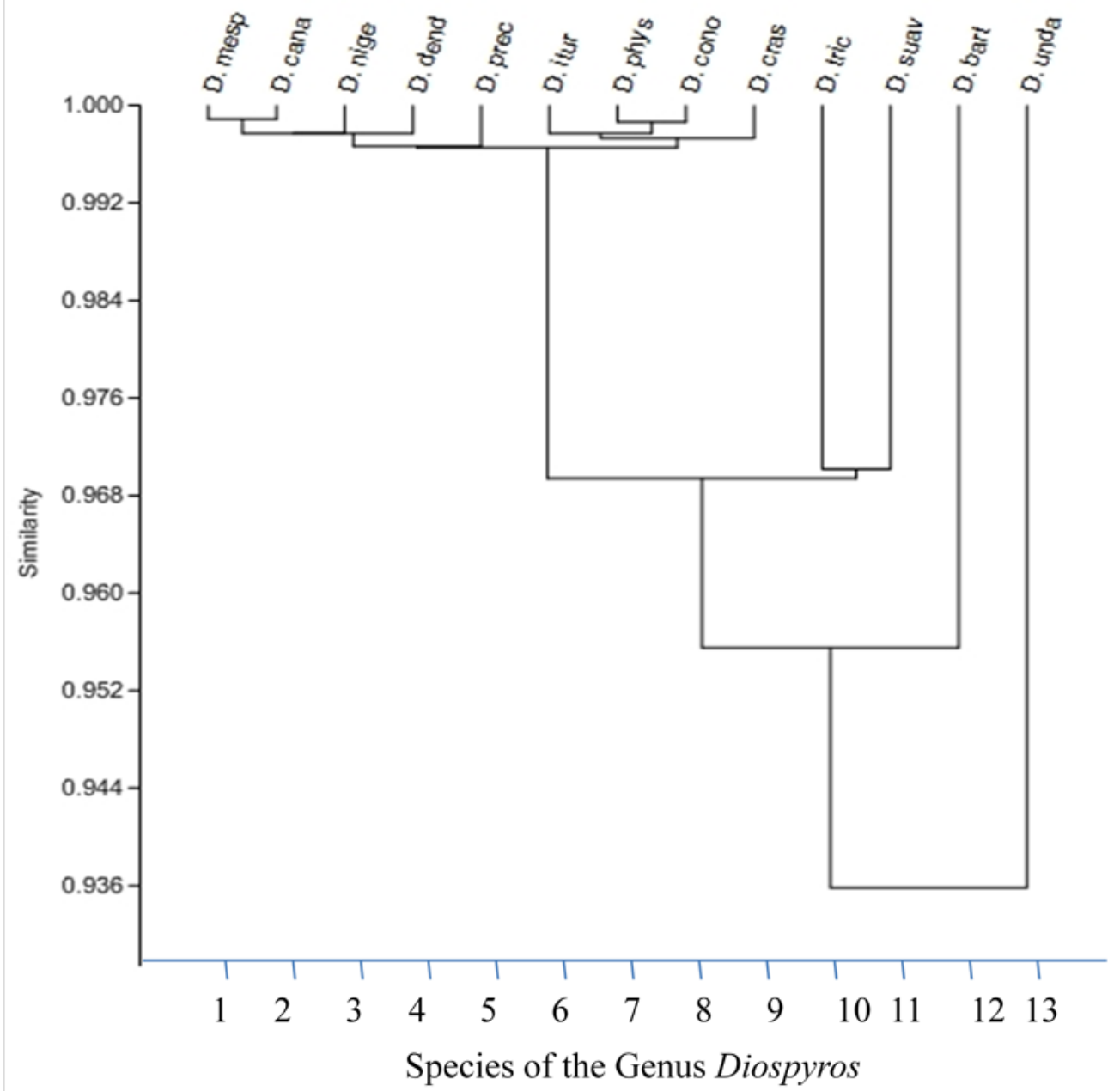

Figure 5. Dendogram of Diospyros species obtained by cluster analysis based on quantitative foliar epidermal and venation characters. 


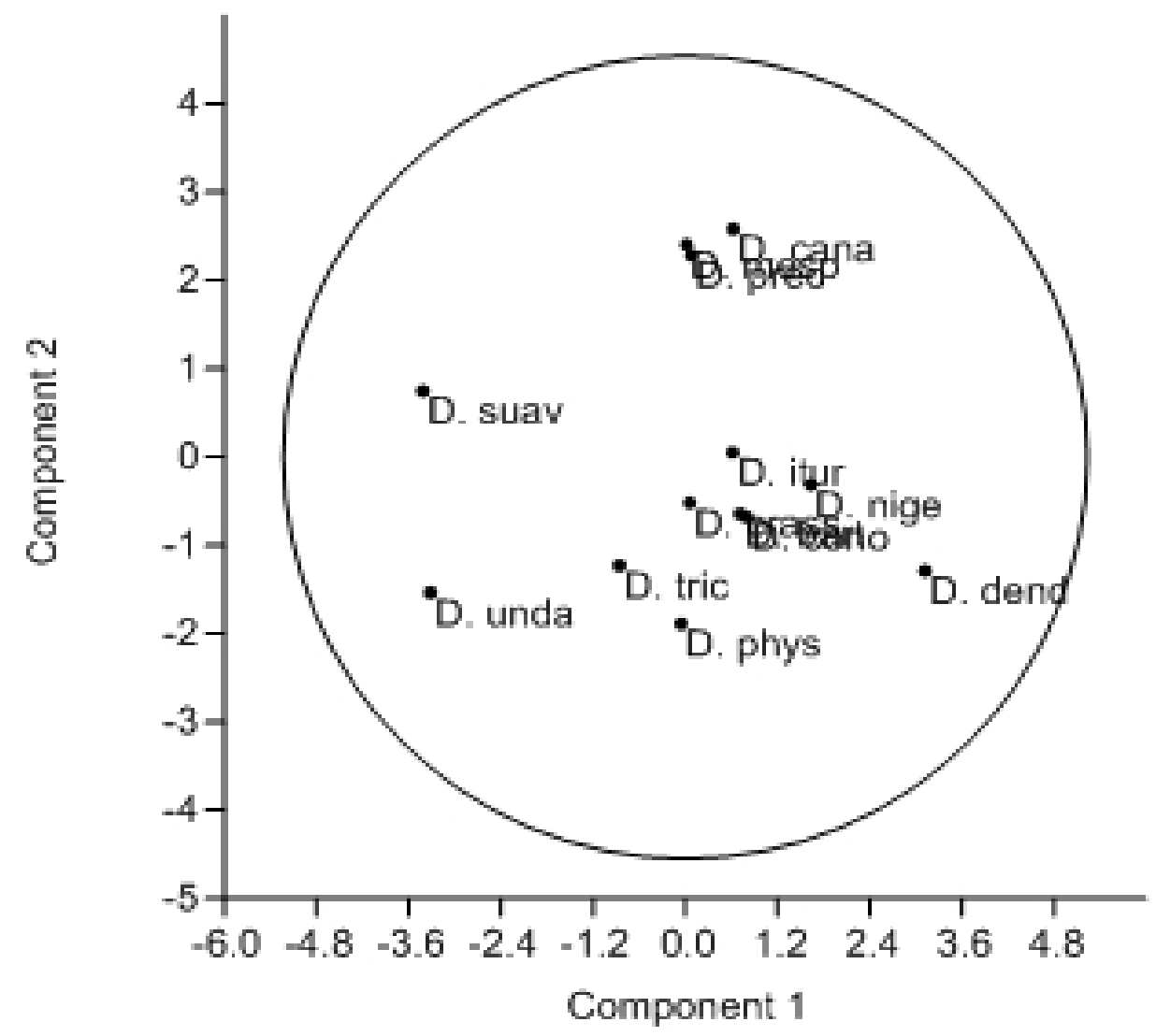

Figure 6. Cluster analysis of Diospyros species based on quantitative foliar epidermal and venation characters.

\section{Conclusion}

This study concluded that foliar epidermis and venation characters are important in the taxonomy of the genus Diospyros. It has revealed additional information for the delimitation and subsequent identification of members of the genus, thereby enhancing the taxonomic revision of the genus.

\section{Acknowledgement}

The authors wish to acknowledge $\mathrm{Mr}$ Abiodun Omole, of the Histology Laboratory, Department of Botany, Obafemi Awolowo University, Ile-Ife for the technical assistance rendered. 


\section{Conflict of interest}

The authors have declared that there is no conflict of interest.

\section{References}

Adedeji, 0. A.; Ajuwon, O.Y.; Babawale, 0. Foliar Epidermal Studies, Organographic distribution and taxonomic importance of trichomes in the Family Solanaceae. International Journal of Botany, v. 3, no. 3, p. 276-282, 2007.

Agboola, S. A. An Agricultural Atlas of Nigeria. Nigeria: Oxford University Press, 1979.

Amos, G. Some siliceous timbers of British Guyana. Carribbean, v. 12, p. 133-137, 1951.

Carlquist, S. Comparative Plant Anatomy. New York: Holt, Rinehart and Winston, 1961.

Casper, T. H. Population genetics and ethnobotany of cultivated Diospyros riojae Gómez Pompa (Ebenaceae), an endangered fruit crop from Mexico. Genetic Resources Crop Evolution, v. 60, p. 2171-2182, 2013. https://doi.org/10.1007/s10722-0130015-z

Faleyimu, O. I.; Agbeja, B. 0.; Akinyemi, 0. State of forest regeneration in Southwest Nigeria. African Journal of Agricultural Research, v. 8, no. 26, p. 3381-3383, 2013.

Halle, F.; Oldeman, R. A. A.; Tomlinson, P. B. Tropical Trees and Forests. Berlin: Springer Verlag, 1978.

Illoh. H. C.; Inyang, U. E. Foliar epidermis and petiole anatomy in some Nigerian Solanum Linn. species in the sub-genus Leptostemon (Bitt.) Dun. Glimpses in Plant Research, v. 12, p. 73-86, 1998.

Levin, G. A. Systematic foliar morphology of Phyllanthoideae (Euphorbiaceae). 1. Conspectus Saint Ann. Missouri Botanical Garden, v. 73, p. 86-98, 1986.

Metcalfe, C. R. Current development in Systematic Plant Anatomy. In: Heywood, V. H. (Ed.). Modern Methods in plant taxonomy. London: Academy Press, 1968. p. 45-57.
$\mathrm{Ng}$, F. S. P. A taxonomic study of the Ebenaceae with special reference to Malesia. Oxford, UK: University of Oxford, 1971. (Ph. D. Thesis).

$\mathrm{Ng}$, F.S.P. The relationships of the Sapotaceae within the Ebenales. In: Pennington, T. D. (Ed.). The genera of Sapotaceae. Kew, UK: Royal Botanic Gardens, 1991

Provance, M. C.; Sanders, A. C. More American black sapotes: New Diospyros (Ebenaceae) for Mexico and Central America. Sida, v. 22, p. 277-304, 2006.

Rammaya, N.; Rao, R. S. Morphology phylesis and Biology of the peltate scale, stellate and tufted hairs in some Malvaceae. Journal of Indian Botanical Society, v. 55, p.75-79, 1976.

Rao, R. S.; Rammaya, N. Structure distribution and taxonomic importance of trichomes in the Indian species of Malvastrum. Phytomorphology, v. 27, p. 40-44, 1977.

Schadel, W. E.; Dickison, W. C. Leaf anatomy and venation patterns of the genus Diospyros. Journal Arnold Arbor, v. 60, p. 8-37, 1979.

Stace, C. A. Cuticular studies as an aid to plant taxonomy. Bulletin British Museum (Nat. Hist.), Botany, v. 4, p. 1-78, 1965.

Ter Welle, B. J. H. Silica grains in woody plants in Neotropics especially Surinam. Leid Botanist. Ser., v. 3, p. 107-142, 1976.

Tutin, C.E. G.; Parnell, R. J.; White, F. Protecting seeds from Primates: Examples from Diospyros spp. in the Lopé Reserve, Gabon. Journal Tropical Ecology, v. 12, p. 371-384, 1996.

Wallnofer, B. The Biology and Systematics of Ebenaceae: A review. Annalen des Naturhistorischen Museums in Wien, B, v. 103, p. 485-512, 2001.

White, F. Ebenaceae. Fl. Zambesiaca, v. 7, no. 1, p. 248-300, 1983.

License information: This is an open-access article distributed under the terms of the Creative Commons Attribution License, which permits unrestricted use, distribution, and reproduction in any medium, provided the original work is properly cited. 